logos_i_ethos_2020_2_(55), s. 167-188

DOI: http://dx.doi.org/10.15633/lie.3812

Karolina Tytko

https://orcid.org/0000-0003-2477-9090

Uniwersytet Papieski Jana Pawła II w Krakowie

\title{
Modele wartości godności człowieka i kwestia sprawiedliwości ${ }^{1}$
}

\section{Wstęp}

Pierwszym celem artykułu jest próba zbadania, przy pomocy eksperymentu myślowego, zależności pomiędzy dwoma kwestiami - teoretyczną wartością przyznaną godności człowieka ${ }^{2}$ oraz sprawiedliwością społeczną ${ }^{3}$. Celem drugim

Karolina Tytko - absolwentka matematyki stosowanej i filozofii. Członkini Interdyscyplinarnego Koła Naukowego Myśli Personalistycznej JPII. Doktorantka na Wydziale Filozoficznym UPJPII w Krakowie, przygotowuje pracę doktorską dotyczącą filozofii matematyki Georga Cantora i Richarda Dedekinda, pod kierunkiem ks. prof. dr. hab. Jerzego Dadaczyńskiego.

\section{i zarazem efektem zrealizowania} celu pierwszego będzie zaproponowanie wspólnej dla personalizmu i utylitaryzmu płaszczyzny. Należy już na wstępie zaznaczyć, że nie mamy zamiaru ani podważać założeń personalistycznych, ani uzupełniać na siłę systemu utylitarystycznego ${ }^{4}$.

1 Artykuł powstał w ramach projektu Nieskończoność i nieskończenie małe w matematyce a filozofia osoby, który został sfinansowany z dotacji celowej na naukę przyznanej przez MNiSW w roku 2018 .

2 Nie jest konieczne do tego realistyczne założenie o istnieniu godności. Przeprowadzamy rozumowanie niejako na metapoziomie teorii personalistycznej i utylitarystycznej.

3 Rozumianej przede wszystkim według definicji Karola Wojtyły zamieszczonej w Elementarzu etycznym.

${ }^{4}$ Nawiązując do dyskusji o argumentacji etycznej (por. D. N. Walton, Ethical Argumentation, Lanham-Toronto-Boulder-Nowy Jork-Plymouth 2009, s. 131-132 oraz J. Synowiec, Model argumentacji etycznej w etyce personalistycznej Karola Wojtyly i Tadeusza Stycznia, Kraków 2014, s. 49), 
Inspiracją do przeprowadzenia tego eksperymentu przy pomocy metody matematycznej ${ }^{5}$ są mnogie przykłady wykorzystywania matematyki nie tylko w naukach ścisłych ${ }^{6}$. Nie będziemy tu opisywać ich szczegółowo, bo metoda matematyczna przedstawiona w niniejszym artykule będzie stosunkowo prosta zarówno z punktu widzenia rozumienia, jak i użycia.

\section{Godność człowieka i osoby}

Możemy mówić o różnych perspektywach godności osoby w personalizmie ${ }^{7}$. Biorąc pod uwagę ontologiczną godność osoby, mówimy o czymś, co nie tyle jest wartością niewspółmierną do wartości materialnych, ile wartością w pewnym sensie nadrzędną ${ }^{8}$, pewną cennością istoty człowieka'.

Spróbujmy przedstawić godność człowieka w perspektywie utylitaryzmu. W utylitaryzmie zakłada się moralną równość wszystkich ludzi ${ }^{10}$.

możemy zaznaczyć, że rozważania na poziomie metaetycznym nie potrzebują elementów perswazji. Wyniki tych rozważań jednak przedstawiają w bardziej wyraźny sposób skutki poszczególnych założeń, przez co lepiej widać funkcjonowanie poszczególnych systemów.

${ }^{5}$ Mowa tu o stosunkowo prostej metodzie modelowania matematycznego, polegającej na przypisywaniu pewnym pojęciom funkcji lub wartości liczbowych i ich porównywaniu oraz obrazowaniu wyników wykresami.

${ }_{6}$ Por. G. Treliński, Stosowane matematyki jako problem dydaktyki matematyki, Kraków 1982; E. Aronson, T. D. Wilson, R. M. Akert, Psychologia społeczna, Poznań 2012, s. 65; J. Dadaczyński, Pojęcie boskiej wiecznej teraźniejszości w kontekście matematycznej analizy niestandardowej, „Logos i Ethos" 34 (2013), s. 31-43; M. Miłkowski, Explaining the Computational Mind, Cambridge 2013.

7 Por. G. Hołub, Osoba w labiryncie decyzji moralnych. Bioetyka w perspektywie personalistycznej, Kraków 2014; Godność pacjenta jako człowieka - norma podstawowa etyki lekarskiej, „Medycyna Praktyczna" 9 (2013), s. 122-124; T. Biesaga, Godność osoby ludzkiej a normy etyczne, w: Spór o naturę ludzką, red. A. Maryniarczyk, K. Stępień, A. Gudaniec, Lublin 2014, s. 567-584.

8 Biesaga pisze: „Godność wskazuje, że osoba jest wartością wartości, a nie odwrotnie, jakoby pewne wartości w osobie stanowiły o jej osobowej godności” (T. Biesaga, Godność a wolność w antropologii Karola Wojtyły, w: Ku rozumieniu godności człowieka, red. G. Hołub, P. Duchliński, Kraków 2008, s. 68).

9 Por. G. Hołub, Człowiek a świat naturalny. Wokół koncepcji egalitaryzmu gatunkowego Paula W. Taylora, „Logos i Ethos” 32 (2012), s. 124.

10 Por. W. Kymlicka, Współczesna filozofia polityczna, Warszawa 2009, s. 63; F. Copleston, Historia filozofii, t. 8, Warszawa 1989, s. 14. 
Oznacza to, że w pewnym sensie zakłada się własność godności człowieka, jakąś jego wartość, przez sam fakt bycia przedstawicielem homo sapiens. Jednak nie jest ona przedstawiana jako główne kryterium moralne, a więc nie przyznaje się jej największej wartości w hierarchii. Kryterium tym jest maksymalizacja użyteczności działania (poprzez dążenie do szczęścia czy przyjemności) ${ }^{11}$. Wśród zalet utylitaryzmu wymienia się odniesienie do racjonalnych rozumowań, opartych na materialistycznej obserwacji świata, oraz postulat traktowania wszystkich ludzi w sposób egalitarny ${ }^{12}$. Jednak w niniejszej pracy okaże się, że mogą to być kwestie kontrowersyjne (niespójne logicznie), zwłaszcza przy różnych sposobach definiowania kryterium użyteczności ${ }^{13}$. W związku $\mathrm{z}$ tym pod znakiem zapytania stoi praktyczna użyteczność założenia o równych prawach każdego człowieka.

Godność, której przypisuje się różne wartości w niniejszym artykule, nie jest żadną z godności wymienianych powyżej ${ }^{14}$, choć opiera się na pojęciu godności ontologicznej w personalizmie. Rozumowanie będzie polegać na metaetycznym założeniu, że istnieje godność człowieka, lecz nie wiadomo, jaką ma wartość. Będziemy rozpatrywać przypadki, gdy godność ma wartość: o (lub $\left.1 / \omega^{15}\right), r, \infty$ lub $\omega$. Przy czym godność osoby według personalizmu utożsamiamy z godnością człowieka, której w założeniu przypisujemy obiektywnie wartość nieskończoną. Należy zaznaczyć, iż nie chcemy podważać w żadnym wypadku teorii personalistycznej i wypracowanego na jej gruncie pojęcia ontologicznej godności

11 Jeremy Bentham, powołując się na naturalny ludzki mechanizm dążenia do przyjemności i uciekania od cierpienia, stworzył podstawy systemu utylitarnego, jako systemu oceniającego moralność działań pod kątem użyteczności. Por. O. Górecki, Utylitaryzm - doktrynalna analiza ewolucji nurtu, „Annales. Etyka w życiu gospodarczym” 14 (2011) nr 1, s. 115-126.

12 Por. O. Górecki, Utylitaryzm - doktrynalna analiza ewolucji nurtu, dz. cyt., s. 121-123.

13 Por. O. Górecki, Utylitaryzm - doktrynalna analiza ewolucji nurtu, dz. cyt., s. 115-126.

14 Fakt, że godności przypisujemy jakąś wartość, nie oznacza, że społeczeństwo, czy też ktokolwiek ją przypisuje. Nie może to być więc godność określana na wzór Seiferta, która oznaczała dar od społeczeństwa czy Boga. Por. T. Biesaga, Godność osoby ludzkiej a normy etyczne, dz. cyt., s. $567-584$.

15 Por. P. Błaszczyk, M. Fila, Cantor on infinitesimals. Historical and modern perspective, „Bulletin of the Section of Logic" 49 (2020) No. 2, s. 155. 
osoby. Wręcz przeciwnie - zainspirowani personalizmem, i tym, jak silnie zaznacza on nieredukowalność i niewyczerpywalność godności osoby $^{16}$, konstruujemy wartość nieskończoną, jako najlepiej opisującą własności godności personalistycznej ${ }^{17}$. Przypisanie owej nieskończonej wartości do godności człowieka oznacza, że możemy traktować ją na równi z godnością osoby. W praktyce również powołujemy się na pojęcie godności. W Powszechnej Deklaracji Praw Człowieka, która jest dokumentem kierowanym i odnoszącym się do każdego obywatela świata, czytamy, że: „Wszystkie istoty ludzkie rodzą się wolne i równe w godności i prawach"18.

Uwzględniając powyższe rozumowanie, pytamy przedstawicieli utylitaryzmu: „Czy jesteście pewni, że nie pomijacie wartości, która mogłaby stanowić najistotniejszy pożytek?"19. Taką bowiem pewność można by było posiadać, gdyby dało się udowodnić, iż nie istnieje ontologiczna godność osoby, lub też że nie można mówić o człowieku jako o osobie ${ }^{20}$.

16 Jest ona jednym z fundamentalnych założeń każdej odmiany personalizmu. Por. T. D. Williams, J. O. Bengtsson, Personalism, https://plato.stanford.edu/entries/personalism/ (2.09.2020).

17 Niniejszym zaznaczamy również, że przypisanie wartości nieskończonej godności osoby nie jest tym samym, co określanie całego bytu człowieka własnością nieskończoności, tak jak na gruncie metafizyki realistycznej określa się Absolut - Boga. Ten ważny aspekt, choć nie podejmujemy się go w niniejszej pracy rozważać, można poddać głębszej analizie w innych opracowaniach.

18 Powszechna Deklaracja Praw Człowieka, Paryż 1948, art. 1, http://libr.sejm.gov.pl/tek01/txt/ onz/1948.html (20.11.2018).

19 Tym bardziej, że jak wskazują niektórzy personaliści, godność, czy inaczej cenność istoty ludzkiej jako centrum, jest wartością często dostrzeganą i docenianą głównie w momentach zagrożenia jej odebrania. Por. A. Szostek, Wolność - prawda - sumienie, „Ethos” 4 (1991) nr 15/16, s. 32 33; A. Pala, Godność - wolność - miłość: struktura dynamizmu życia osobowego człowieka w ujęciu Karola Wojtyty, „Logos i Ethos” 50 (2019) nr 2, s. 7-25; K. Jaspers, Sytuacje graniczne, w: R. Rudziński, Jaspers, Warszawa 1978, s. 186-198.

20 Ta sytuacja przypomina bardzo pewien matematyczny, czy raczej filozoficzno-matematyczny problem, dotyczący niesprzeczności, ale również niezależności (między innymi) hipotezy continuum od teorii mnogości. Por. W. B. Easton, Powers of regular cardinals, „Annals of Mathematical Logic” 1 (1970), s. 139-178; K. Wójtowicz, Status hipotezy continuum w świetle koncepcji Woodina, „Filozofia Nauki” 76 (2011) nr 4, s. 67-82. Pomimo formalnych dowodów na niezależność hipotezy continuum od ZFC (Zermelo-Fraenkel set theory with the axiom of choice, tj. aksjomatyka teorii mnogości Zermela-Fraenkla $\mathrm{z}$ aksjomatem wyboru), Woodin próbował wykazać, iż hipoteza ta jest naturalna dla teoriomnogościowego podejścia. Zob. H. Woodin, The continuum hypothesis, Part I, II, „Notices of the AMS” 48 (2001) No. 6/7, s. 567-576, 681-690. Podobnie jest z rozumowaniem 
Przy czym, przy podejmowanych próbach należałoby wykazać, że zakładana ontologiczna godność osoby jest całkowicie oddzielona od ewolucyjnej struktury homo sapiens ${ }^{21}$. Tych stwierdzeń jednak nie da się udowodnić $^{22}$. Stąd pomysł nawiązania międzyteoretycznego dialogu, na zasadzie analizowania konsekwencji przyjmowania różnych wartości godności człowieka.

\section{Struktura eksperymentu}

Niniejszym spróbujemy sprawdzić, czy są, a jeśli tak, to jakie, następstwa logiczne poszczególnych (rozłącznych co do treści) hipotetycznych stwierdzeń o wartości godności człowieka dla rozumienia i analizowania problemu sprawiedliwości. Jeśli weźmiemy pod uwagę różne możliwości przypisywania wartości godności człowieka, okazuje się, że można rozróżnić dwa podstawowe przypadki. Po pierwsze, możemy przyjąć, że wartość godności osoby ludzkiej jest skończona. Wiążą się z tym dwie opcje: że wartością godności jest pewne $G$ skończone, oraz $G=0$ (czy raczej $1 / \omega^{23}$ ). Drugą opcją jest przyjęcie, że wartość godności osoby ludzkiej jest nieskończona. Tu również pojawiają się dwie opcje, ale o tym później.

w niniejszym artykule - człowieczeństwo i jego transcendentność, o której wspomina Ingarden (zob. R. Ingarden, Książeczka o człowieku, Kraków 2017) nie jest czymś, co można w pełni formalnie usankcjonować.

21 Warto przywołać w tym miejscu nowy projekt teologii ewolucyjnej, w którym Wojciech Grygiel proponuje nowy paradygmat, ukazujący (zgodnie ze ścisłą nauką) powołanie człowieka jako dojrzewającego na drodze ewolucji do przyjmowania postaw altruistycznych. Zob. W. Grygiel, What is Invariant? On the Possibility and Perspectives on the Evolutionary Theology, „Studia KoszalińskoKołobrzeskie" 25 (2018), s. 83-101, DOI: 10.18276/skk.2018.25-05.

${ }^{22}$ Choćby z uwagi na teorię umysłu ucieleśnionego. Por. S. Gołota, Dylematy mózgu. Poznanie i emocje w procesach oceny moralnej, Toruń 2019; M. Hohol, K. Cipora, Perspektywy i granice ucieleśnionego poznania matematycznego, w: Filozofia matematyki i informatyki, red. R. Murawski, Kraków 2015, s. 119-140.

${ }^{23}$ Por. z definicją wielkości nieskończenie małej w ciele algebraicznym w: P. Błaszczyk, M. Fila, Cantor on Infinitesimals. Historical and Modern Perspective, „Bulletin of the Section of Logic” 2020 No. 2, s. 155. 
Zdefiniujmy teraz pojęcia, które będziemy wykorzystywać w trakcie modelowania matematycznego - pojęcie wartości godności $(g)$, wartości życia $(w z)$, pojęcie materialnych warunków początkowych $\left(m_{0}\right)$ oraz materialnej wartości $(m)$. Wszystkie te pojęcia określają wartości danej jednostki osobowej. Należy zaznaczyć, że istotne będzie dla kontekstu sprawiedliwości rozważanie zbioru minimum dwuosobowego. Dodatkowo, jeśli wybieramy hipotetycznie, że wartość godności jest równa $G$, to dla każdej osoby jest ona taka sama. Różnią się między sobą tylko wartości materialne i materialne warunki początkowe każdej osoby oraz wyliczana z nich wartość życia $(w z)$ - przez sumowanie ${ }^{24}$ wartości materialnej $(m)$ w danym momencie $t$ oraz wartości godności $(G)$.

Dodatkowymi pojęciami, które możemy zdefiniować, będzie tryb życia jednostki, na który składają się praca i konsumpcja. Pracą będziemy nazywać takie działania jednostki, które mają na celu powiększać pewne wartości materialne jej życia lub życia innych osób. Konsumpcją zaś działania jednostki, które wykorzystują zasoby materialne jej życia lub życia innych osób (a koniec końców pomniejszają te zasoby). W przypadku pracy zakładamy ponoszenie pewnych kosztów w postaci obniżenia jakości życia, tj. wygody funkcjonowania. W przypadku konsumpcji dopuszczamy pewne zyski co do tej jakości. Zaznaczmy, że wartość materialną życia jednostki wyceniamy w kontekście jej pozycji w danym społeczeństwie, które funkcjonuje według pewnych kryteriów i ma własną hierarchię wartości materialnych (użytkowych). Natomiast jakość życia to ocena wygody (wydolności) funkcjonowania względem: 1. jej warunków początkowych, 2. oraz stosunku konsumpcji do pracy. Zakładamy również, że istnieje dla każdej osoby pewien ustalony stosunek konsumpcji do pracy $k w_{0} / p$, który jest korzystny, tj. przy optymalnej stabilizacji wartości życia, optymalizuje również jego jakość (względem

${ }^{24} Z$ uwagi na różne „wymiary” wartości godności oraz wartości materialnych lepiej byłoby wartość życia zdefiniować jako iloczyn wartości materialnych i wartości godności, gdyż wtedy oznaczałoby to, zgodnie zresztą z personalistycznym podejściem, że godność nadaje w pewnym sensie wartość wszystkim własnościom materialnym człowieka. Jednak chcemy, aby rozumowanie było możliwie jak najbardziej niezobowiązujące z ontologicznego punktu widzenia i wybieramy słabsze działanie, tj. dodawanie. 
warunków początkowych). Dopuszczamy także sytuacje ekstremalne, takie jak dziedziczone wykluczenie społeczne czy dziedziczone społeczne „uprzywilejowanie” ${ }^{25}$, w których praca lub jej brak nie ma zauważalnego wpływu na wartość lub jakość życia człowieka lub ten wpływ działa odwrotnie niż zazwyczaj.

Przyjmijmy, że pojęcie wartości życia danej jednostki będzie określało sumę wartości wszystkich aspektów dotyczących tej istoty ludzkiej (tj. na przykład status materialny, uroda czy szerzej fizjologia, zdrowie, status społeczny, szczególne uzdolnienia) oraz wartość godności, czyli wartość istoty ludzkiej samej w sobie ${ }^{26}$. To znaczy, jeśli mamy wartość materialną dla chwili $t$ równą $m$, wartość godności człowieka równą $G$, to wartość życia jest równe $m+G$. Zauważmy, że dla każdej chwili w życiu każdej osoby, za wyjątkiem chwili zerowej, możemy znaleźć zarówno czynniki zewnętrzne, jak i wewnętrzne, wpływające na zmiany wartości życia. W celu uproszczenia modelu rezygnujemy $\mathrm{z}$ analizowania $\mathrm{z}$ czynników zewnętrznych zmieniających drastycznie wartość materialną czy jakość życia jednostki w trakcie trwania tego życia.

Materialnymi warunkami początkowymi będziemy nazywali te aspekty życia danej jednostki, które są przypisane w chwili zerowej tej jednostce i które są niezależne od niej samej. Za takie warunki uważamy pewne porównywalne materialne wartości, niezależne od danej osoby, „nadane jej” na początku życia. W trakcie trwania życia jednostka w zależności od wzrostu/zmniejszania się stosunku $k / p$, zmniejsza/zwiększa wartość materialną lub jakość swojego życia. Przyjmujemy, że dla danego społeczeństwa istnieje tzw. porządek liniowy określający pozycję społeczną każdego członka społeczeństwa według określonej hierarchii wartości.

25 Innymi słowy, dziedziczenie nierówności społecznych. Por. W. Woźniak, Nierówności społeczne i ich dziedziczenie jako problem strukturalny i polityczny, red. B. Kłos, w: J. Szymańczak, Nierówności społeczne w Polsce, Warszawa 2014, s. 73-94.

${ }^{26}$ Przy tym należy rozróżnić: wartości materialne, mierzalne jako „wartości dla osoby” oraz wartość godności osoby/człowieka utożsamianej tutaj z „wartością osoby”/człowieka (wg rozróżnienia Karola Wojtyły, zob. K. Wojtyła, Miłość i odpowiedzialność, Lublin 2001, s. 109). 


\section{Analiza wybranych przypadków}

Przejdźmy zatem do studium przypadków. Chcemy analizować wykresy przedstawiające zmiany wartości życia przykładowych osób $x, y, z$ w czasie trwania ich życia (oś $\mathrm{Y}$ - wartość życia, oś $\mathrm{X}$ - wskaźnik upływu czasu). Zakładamy, że każda z tych osób rodzi się i umiera odpowiednio w tych samych momentach czasowych, że życie każdej z tych osób trwa tyle samo. Zmiany wartości życia będą zależały od trybu życia, na który składać się będzie praca i konsumpcja. Zaburzenie stosunku pracy do konsumpcji będzie skutkowało przeważnie albo obniżeniem wartości życia, albo obniżeniem jego jakości. Choć wartość życia należy odróżnić wyraźnie od jakości życia, to jednak dopuszczamy, że obie te właściwości będą na siebie w jakiś sposób wpływały.

Przykładem obrazującym życie jednostki $x$ może być dziecko rolnika, które odziedziczy po rodzicach ziemię, jednak aby się z niej utrzymać, musi włożyć w to dużo pracy (załóżmy, że jego zdrowie mu na to pozwala). Natomiast przykładem dla jednostki $z$ - dla kontrastu - niech będzie syn właścicieli dobrze prosperującej firmy, który aby korzystać z majątku rodziców, winien jedynie stawiać się na cotygodniowych zebraniach zarządu. Codzienność tych dwóch przykładowych ludzi jest bardzo zróżnicowana pod kątem stosunku pracy do konsumpcji (zakładamy, że zdrowie jednostki $z$ jest porównywalne ze zdrowiem jednostki $x$, jak i reszta uwzględnianych aspektów). Jednostka $x$ musi pracować w trybie ciągłym, jednostka $z$ w trybie ciągłym konsumuje. Dla lepszego opisania sytuacji, w układzie współrzędnych umieszczony jest trzeci wykres - dotyczy on jednostki $y$, której przykładem może byćc ${ }^{27}$ dziecko średniozamożnych rodziców, którzy umożliwiają mu wejście w dorosłość, bez ponoszenia większych kosztów czy to w odniesieniu do wartości, czy też jakości życia.

27 Może być - lecz nie musi. Przykłady tutaj podane nie przesądzają o sposobie wyceniania dóbr materialnych jednostek w danym społeczeństwie, lecz wskazują na taką możliwość. 
wartość życia

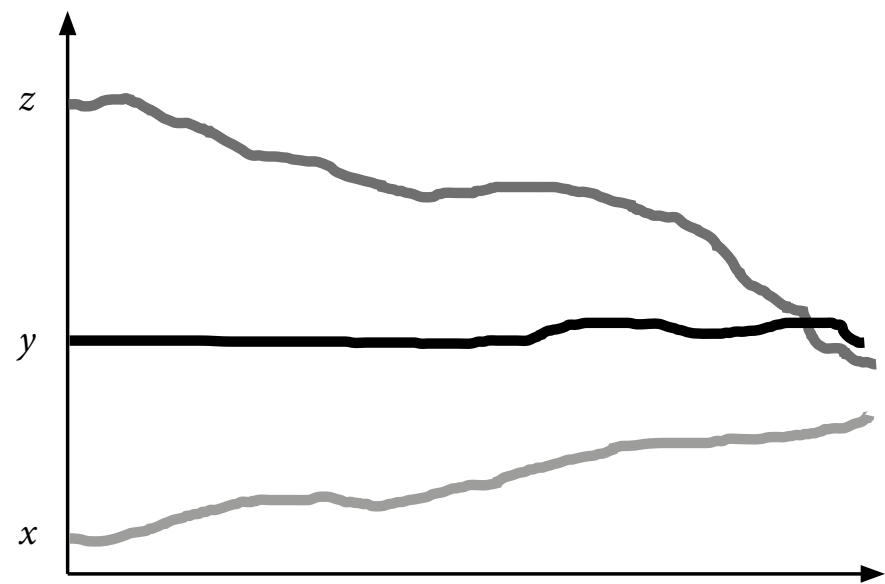

Rys. 1.

czas

W pierwszym przypadku (Rys. 1) przyznajemy zerową wartość godności osoby $(x+0=x ; y+0=y ; z+0=z)$. Dobrze ujął zasady pasujące do tego przypadku Nietzsche, pisząc: „Lecz nie mogłoby być większego i fatalniejszego nieporozumienia, niż gdyby szczęśliwi, udani, mocni na ciele i duszy poczęli wątpić o swym prawie do szczęścia"28. Wartość życia jest zależna jedynie od materialnych warunków początkowych życia człowieka oraz stosunku pracy i konsumpcji danej jednostki. W ekstremalnych przypadkach jednak można sprowadzić wszystko do warunków początkowych.

W przypadku drugim (Rys. 2), tj. przyjęcia pewnej skończonej (rzeczywistej) wartości godności $G$, wykres wygląda bardzo podobnie jak w przypadku nieuwzględnienia wartości godności (tj. przyznania jej wartości 0$)$ - jest jedynie przesunięty o wektor $[0, G]$. Ponadto warto zauważyć, że jakakolwiek duża by wybrana wartość nie była, zawsze możemy znaleźć taką wartość $r$ należącą do $R$ (zbioru liczb rzeczywistych), że $r>G$. 


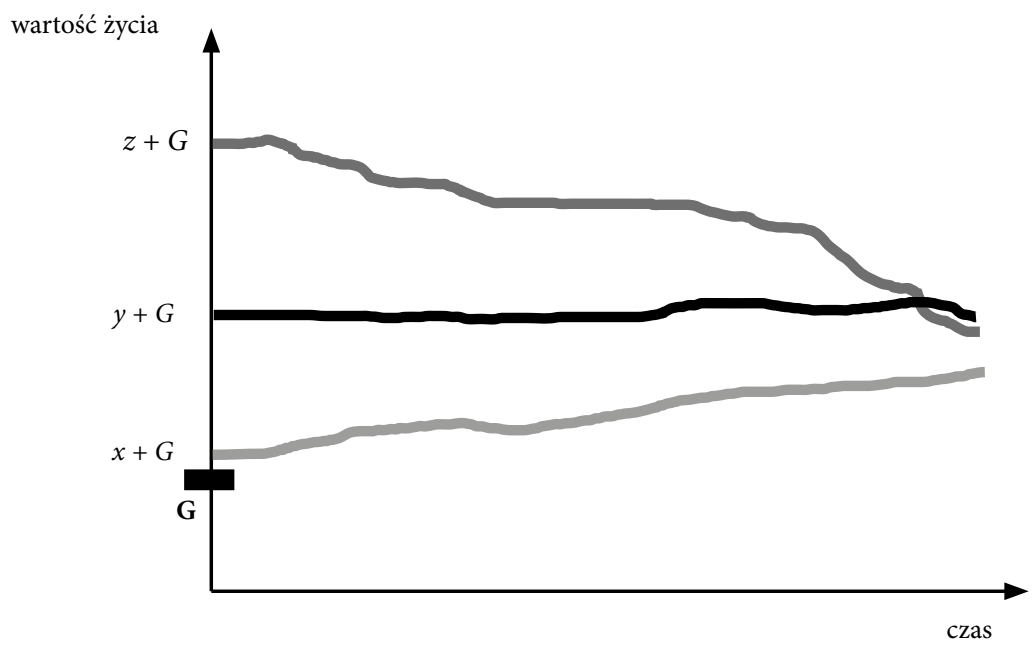

Rys. 2.

Co oznacza trzeci przypadek (Rys. 3)? Niech symbol nieskończoności oznacza granicę niewłaściwą $\infty$ wykorzystywaną w matematycznej analizie funkcji liczb rzeczywistych. Dla wartości życia w trakcie jego trwania każdej osoby otrzymujemy wykres funkcji, która w każdym punkcie z dziedziny przyjmuje wartość mającą granicę w plus nieskończoności ${ }^{29}$. Nazwijmy ten model dla uproszczenia modelem matematyki klasycznej ${ }^{30}$.

29 Definicja granicy niewłaściwej plus nieskończoność funkcji w punkcie $x_{0}$ brzmi: dla każdego $M$ rzeczywistego istnieje $\delta>0$, że dla każdego $x$ z otoczenia $x_{0}$ : Jeśli $\left|x-x_{0}\right|<\delta=>f(x)>M$. W tym przypadku $x_{0}$ przebiega wszystkie $x$ ze zbioru dziedziny funkcji $f$. Por. G. M. Fichtenholz, Rachunek różniczkowy i całkowy, Warszawa 2012.

30 Należy pamiętać, że matematyka klasyczna posługuje się również wielkościami nieskończenie dużymi na różne sposoby. Nie wszystkie z nich są przedstawione w artykule (np. liczby pozaskończone kardynalne czy porządkowe w teorii mnogości). 


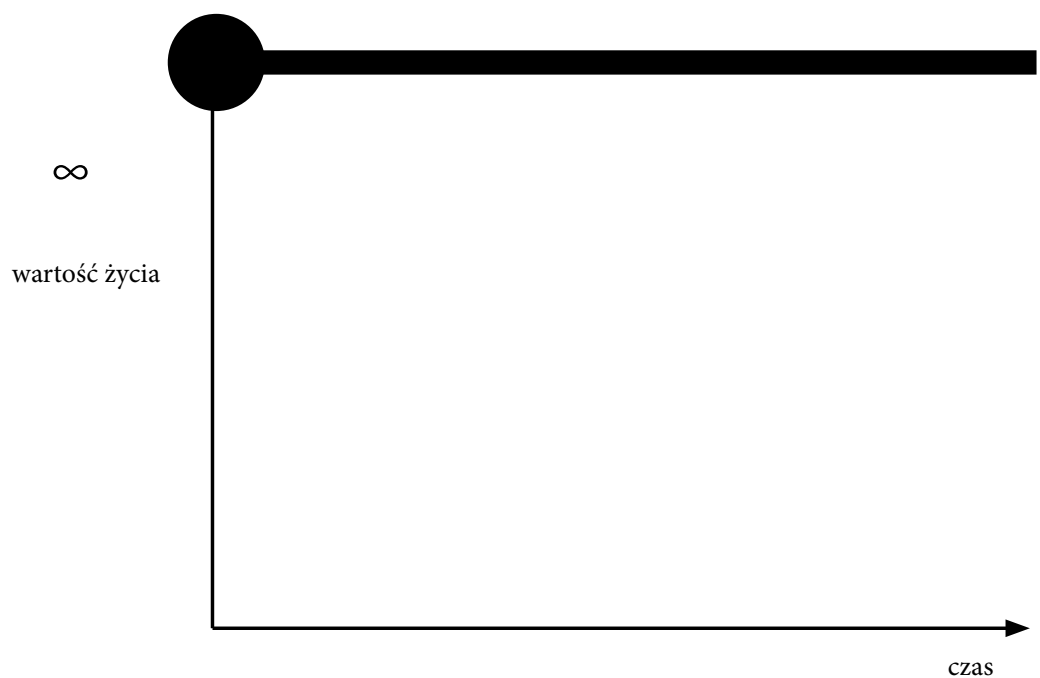

Rys. 3.

Możemy jednak wziąć model (Rys. 4) liczb hiperrzeczywistych ${ }^{31}$ (tj. takich liczb, do których należą nieskończenie małe, jak i nieskończenie duże liczby). Wtedy znów widzimy różnice pomiędzy wartościami początkowymi oraz pomiędzy wykresami funkcji określających zmiany wartości życia w czasie, w zależności od trybu życia (tj. od stosunku konsumpcji do pracy) konkretnych osób. Należy przy tym zaznaczyć, że w odróżnieniu od pierwszego i drugiego przypadku, tu w porównaniu do nieskończonej wartości godności, te różnice są nieskończenie małe ${ }^{32}$.

31 Por. K. D. Stroyan, Mathematical Background: Foundations of Infinitesimal Calculus, New York 1997, s. 8.

32 Dodatkowo istnieją podejścia, które zmieniają skalę tak, aby rzeczywiste różnice traktować jak nieskończenie małe, a wartości nieskończone jak rzeczywiste. Może to okazać się pomocne w praktyce $-\mathrm{w}$ analizowaniu problemów. 


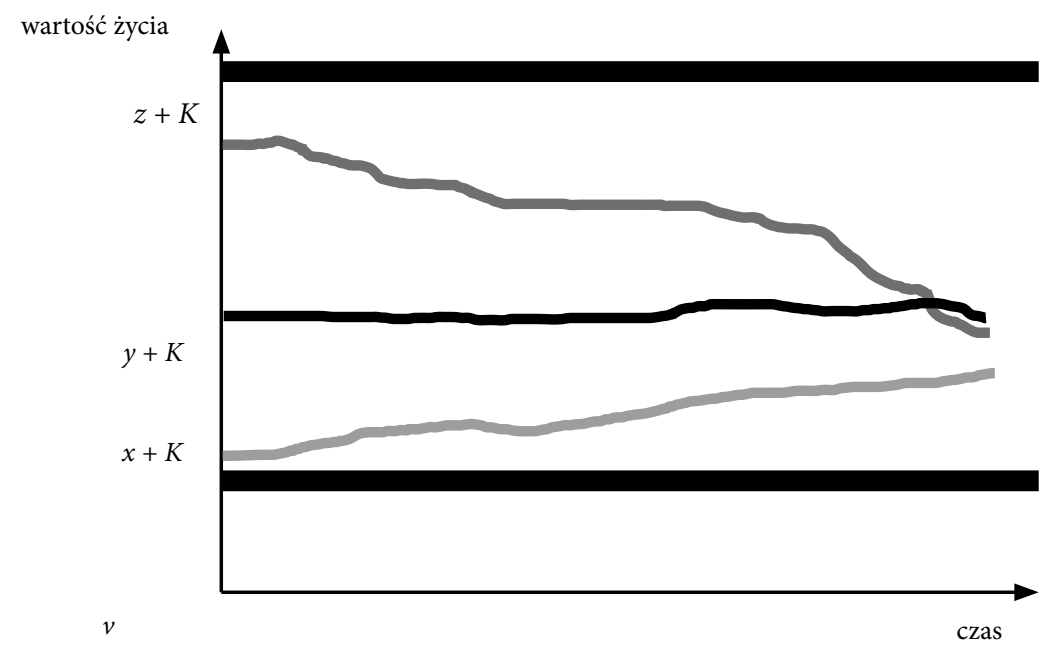

Rys. 4.

\section{Sprawiedliwość w kontekście modelów godności}

Trzecia i czwarta opcja przedstawiana w eksperymencie to model tożsamy z personalistycznym podejściem Karola Wojtyły, gdzie osoba posiada niezależną wartość fundamentalną (nieskończoną wartość godności) i wartości szczegółowe (wartości materialne, wartości dla osoby), nawet w sumie wzięte, nie wyczerpują tej pierwszej ${ }^{33}$. Opcja pierwsza i druga przedstawia systemy, takie jak np. transhumanizm, biocentryzm, gdzie osoba ludzka jest czymś redukowalnym do świata materialnego ${ }^{34}$.

Definicja sprawiedliwości społecznej przyjęta w niniejszej pracy jest raczej kwestią idei niż zbioru konkretnych zasad ${ }^{35}$. Miejsce dla realizo-

33 Por. K. Wojtyła, Miłość i odpowiedzialność, Lublin 2001, s. 109.

34 Por. G. Hołub, Human Enhancement, the Person, and Posthuman Personhood, „Ethics \& Medicine. An International Journal of Bioethics” 32 (2016) no. 3, s. 171-183.

35 Mamy tu na myśli ogólne rozumienie sprawiedliwości przez Józefa Tischnera. Zob. J. Tischner, Etyka solidarności oraz Homo sovieticus, Kraków 2005. 
wania tej idei to relacje międzyludzkie oraz ustalony porządek społeczny. Pomysł pochodzi z definicji sprawiedliwości przedstawionej przez Wojtyłę w Elementarzu etycznym ${ }^{36}$, choć tak naprawdę sięga korzeniami starożytności ${ }^{37}$. Dodatkowo będziemy się inspirować analizą dzieła Michaela Sandela Sprawiedliwość. Jak postępować słusznie? ${ }^{38}$. Dzięki niej możemy połączyć ideę sprawiedliwości z oceną konsekwencji działań pojedynczych ludzi oraz moralnością organizowania ładu prawnego w danym społeczeństwie.

W Elementarzu etycznym Wojtyły czytamy, że: „W sprawiedliwości chodzi zawsze o jakieś dobro, które tak czy inaczej ma być rozliczone, rozdzielone pomiędzy osoby. [...] Chodzi zaś o to, ażeby dobro było rozdzielone równo"39. Zaznacza on, że kwestia ta dotyczy relacji najpierw człowiek-człowiek, a w następstwie również relacji człowiek-społeczeństwo. A także, że z racji sprawiedliwości rozdzielczej wynikają w ramach tych relacji pewne uprawnienia, ale i zobowiązania ${ }^{40}$. Nasuwają się w tym miejscu dwa pytania, bez względu na wybierany system etyczny: kto odpowiada za "rozdzielenie” warunków początkowych? oraz czy z racji zróżnicowanego rozdzielenia warunków początkowych wynikają jakieś dodatkowe uprawnienia i zobowiązania? Kwestia sprawiedliwości, którą rozważamy w niniejszej pracy, w kontekście pytania o warunki początkowe, to zasadniczo kwestia tego, czy sprawiedliwe jest pomijanie powyższych dwóch pytań przy wyborze systemu etycznego. Zwłaszcza w kontekście osoby, która przez (wyłącznie) swoje warunki początkowe jest skazana na przegraną.

Przyjrzyjmy się teraz, jak wygląda kwestia sprawiedliwości w różnych modelach godności. Sprawiedliwość zdefiniowana w pierwszym i drugim przypadku (Rys. 1 oraz Rys. 2) jest niemożliwa do zrealizowania.

36 K. Wojtyła, Elementarz etyczny, Lublin 1983.

37 Chodzi o stwierdzenie, że czynem sprawiedliwym jest taki, który oddaje każdemu (człowiekowi, wspólnocie) to, co się mu należy. Por. Platon, Państwo, t. 1, Warszawa 1991, 332c; Arystoteles, Etyka nikomachejska, Warszawa 1982, 1130-1131.

38 M. J. Sandel, Sprawiedliwość. Jak postępować słusznie, Warszawa 2013.

39 K. Wojtyła, Elementarz etyczny, dz. cyt., s. 89.

${ }^{40}$ Por. K. Wojtyła, Elementarz etyczny, dz. cyt., s. 89. 
Choćby $\mathrm{z}$ racji braku możliwości zmiany wartości pewnych aspektów życia (np. zdrowia, z jakim dana osoba przychodzi na świat). Jeśli materialne warunki początkowe mają tak niską wartość $m$, że żadna praca danej jednostki nie jest w stanie zwiększyć tej wartości do wymaganego minimum, niezbędnego do przeżycia ${ }^{41}$, wtedy ta osoba jest zdana na zrozumienie bądź niezrozumienie drugiej osoby lub społeczeństwa. Warunki początkowe nie są rozdzielone sprawiedliwie, a z powyższych systemów nie wynika bezpośrednio, że pomaganie słabszym jest moralnie dobre.

Sprawiedliwość w trzecim przypadku (Rys. 3) w modelu matematyki klasycznej jest w zasadzie zapewniona. Bezproblemowo stwierdzamy równą wartość życia każdej osoby. W tym modelu pomijamy prozaiczne, materialne warunki początkowe. O ile podejście to może stanowić dla każdej osoby/człowieka, pewne zabezpieczenie przed zbytnim zamartwieniem się znacznym i niezależnym zróżnicowaniem warunków początkowych, pojawia się jednak pytanie: czy oznacza to, że należy pomijać kwestię zróżnicowania „warunków początkowych”? Zwłaszcza kiedy mamy możliwość (por. model niestandardowy Rys. 4) wziąćje pod uwagę.

\section{Analiza konsekwencji poszczególnych wyborów}

W przypadku nieskończonej wartości można wybrać model klasyczny lub model niestandardowy. Jednak nie jest to do końca całkiem bez znaczenia, np. w fizyce, o czym pisał wybitny polski uczony, autor cenionych monografii i publikacji naukowych w zakresie metod matematycznych w mechanice, Czesław Woźniak ${ }^{42}$. Tak samo nie do końca bez znaczenia jest to, co wybierzemy, jeśli chodzi o etykę.

W modelu klasycznym, uwzględniając nieskończoną godność, uznajemy równe prawo do życia każdej osoby. $\mathrm{W}$ bioetyce nazywa się

${ }^{41}$ Możemy wtedy powiedzieć, że taka niewystarczająca do przeżycia wartość materialna $m$ jest nieskończenie mała. Do pominięcia - tak się bowiem traktuje nieskończenie małe wartości w fizyce.

42 Zob. C. Woźniak, Analiza niestandardowa w mechanice newtonowskiej punktu materialnego, „Journal of Theoretical and Applied Mechanics” 19 (1981), s. 355-374. 
to zasadą świętości życia ${ }^{43}$. W relacji dwóch jednostek ludzkich, z których jedna ma gorszą pod względem materialnym (tj. głównie w kontekście warunków początkowych) jakość życia, a druga znacznie lepszą, z niezależnych od nich powodów, żadna z nich nie ma uprawnień ani zobowiązań, aby ten fakt uwzględnić - w końcu żadna z osób za to nie odpowiada. Nie jest jednak oczywiste, że pominięcie tej kwestii w żaden sposób nie jest niesprawiedliwe dla osób z gorszymi warunkami początkowymi ${ }^{44}$.

Przechodząc do modelu niestandardowego, trzeba zauważyć, że sprawiedliwość na płaszczyźnie relacyjnej wymaga uwzględnienia tych różnic. Uwzględniając zróżnicowanie warunków początkowych (co nie jest tożsame z zaradzeniem danemu problemowi) bądź nawet wykazując gotowość do tego, bierzemy pod uwagę dodatkową wartość (dodatnią bądź ujemną w porównaniu z naszą) wpływającą na całokształt wartości życia innej osoby. A co za tym idzie - możemy wnikliwiej ocenić tryb i życie danej osoby ${ }^{45}$. Warto również dodać, że teorie niestandardowe nie zmieniają nic w klasycznych - są jedynie dodatkiem, rozszerzeniem jak pisał Edward Nelson ${ }^{46}$. A nawet następstwem logicznym - jak pisał Abraham Robinson ${ }^{47}$.

\section{Podsumowanie}

Podsumowując, musimy ostatecznie dopuścić, że dla każdego człowieka istnieje możliwość wyboru zarówno wartości godności osoby,

43 Por. A. Schweitzer, More from the Primeval Forest, London 1931. Schweitzer, idąc dalej, wypracował tzw. zasadę czci dla życia, która obejmuje nie tylko osoby, ale wszystko, co żyje.

${ }^{44}$ Należy przy tym zaznaczyć, że nie mówimy o ustalonej grupie osób z gorszymi warunkami początkowymi czy o grupie z lepszymi warunkami. Zawsze istnieje zależność od tego, jakie osoby i z kim porównujemy. A także od tego, w jakim to kontekście robimy.

${ }^{45}$ W kontekście powyższego rozumowania jaśniejsza staje się biblijna przypowieść o talentach - oczywistą niesprawiedliwością jest brak wkładu pracy osoby, która dużo posiada, w kontekście maksimum pracy włożonej przez osobę, która posiada bardzo niewiele. Posiadać można przy tym różne rzeczy bądź przymioty.

46 Zob. E. Nelson, Internal Set Theory, http://web.math.princeton.edu/ nelson/ (2.09.2020).

47 Zob. A. Robinson, Non-standard Analysis, Princeton 1996, s. 1-4. 
jak i modelu matematycznego, w którym się tę wartość umiejscawia ${ }^{48}$. Należy jednak zaznaczyć, że zarówno przyznanie nieskończonej wartości godności, jak i uwzględnienie szerszego systemu (modelu liczb hiperrzeczywistych, zawierającego nieskończenie duże i nieskończenie małe) może mieć na celu sprawiedliwszą, ponieważ biorącą pod uwagę szczegółową ocenę trybu życia poszczególnych osób.

Społeczeństwo w takim modelu może być bardziej ekonomiczne, ponieważ umiejętniej rozkładałoby obciążenia na wszystkie jednostki - można powiedzieć bardziej sprawiedliwie. Jednostka najsłabsza być może dzięki pomocy innych jednostek, obok obowiązkowej pracy własnej, miałaby szansę na przetrwanie. W przeciwnym razie, jednostka najmocniejsza ma prawo wzmacniać swoją pozycję kosztem pominięcia wartości tych najsłabszych ${ }^{49}$. Tak jest w przypadku utylitaryzmu, w którym, o ile nie założymy, że godność człowieka ma wartość nieskończoną, można wyceniać ludzi pod kątem ich użyteczności. Wartość człowieka nie jest wówczas „rozdzielana” w sposób egalitarny ${ }^{50}$, lecz jest związana ostatecznie, szczególnie w ekstremalnych przypadkach, z warunkami początkowymi. W tym kontekście sprawiedliwość w postaci uwzględniania gorszych warunków początkowych innych ludzi traci sens.

Podsumowując, sprawiedliwość w powyższej pracy nie była rozpatrywana jedynie w kontekście posiadania. Braliśmy również pod uwagę możliwości działania każdej osoby, w tym możliwość wyboru wartości

48 Można tutaj nawiązać do Michaela Sandela, który w bardzo jasny sposób przedstawił różnice między pewnymi systemami etycznymi, jako różnice co do najwyższych wartości w hierarchii. Zob. M. J. Sandel, Sprawiedliwość, dz. cyt., passim.

49 Nawiązując w tym miejscu do jeszcze innego pojęcia, można opisać pierwszy przykład społeczeństwa jako społeczeństwo solidarne. Drugie - jako społeczeństwo, w którym solidarność nie jest pożądana. „Solidarność to słowo wywodzące się z języka łacińskiego: soliditas (gęstość, moc); solidus (gęsty, mocny, trwały) [...]. W skrajnym przypadku wiedzie do pełnego utożsamiania interesu jednostki z interesem innej osoby lub pewnej zbiorowości" (J. Rodzińska, Solidarność: definicja i konteksty, „Etyka” 48 (2014), s. 58-59).

50 Por. W. Zuziak, Uczciwość a ideały społeczne. W poszukiwaniu nowego wzorca, „Logos i Ethos” 49 (2019) nr 1, s. 168-172, DOI: http://dx.doi.org/10.15633/lie.3440 
godności ${ }^{51}$. Tak pojmowaną sprawiedliwość można analizować na trzy sposoby - w relacji dwóch jednostek, w relacji jednostki ze społeczeństwem oraz na odwrót ${ }^{52}$. Minimalizowanie obciążeń w najsłabszych punktach to pomoc całej, zbudowanej z tych punktów, strukturze ${ }^{53}$. Można więc powiedzieć, że idea maksymalizacji sprawiedliwości pociąga za sobą ideę solidarności. Oczywiście należy zaznaczyć, iż w powyższym kontekście pomoc społeczeństwu to nie tylko pomoc „biednym", ale współmierna (do własnych możliwości) praca każdej jednostki na rzecz tegoż społeczeństwa ${ }^{54}$. Podważa się tym samym (przynajmniej w części) mogące się w tym miejscu pojawić się utylitarystyczne zarzu$t^{55}$, że przez przymus pomagania najsłabszym opóźnia się bądź hamuje rozwój całego społeczeństwa.

Dodatkowo zauważmy, że kwestia ewentualnego pożytku z doświadczenia czy afirmacji godności osoby, zarówno u siebie, jak i u innych ludzi, to problem stosunkowo nowy i niezbadany. Jednym z jego aspektów są relacje interpersonalne ${ }^{56}$. Zakładamy, że owa pożyteczność nie tylko umożliwia ewentualny przepływ „pomocowy”, ale przede wszystkim go wzmacnia, tj. niesie korzyść dla jakości życia poszczególnych jednostek biorących udział w doświadczeniu relacji personalistycznej ${ }^{57}$.

${ }^{51}$ Czyli, według Wojtyły, nie tylko analizowaliśmy podział dóbr, których w kontekście kwestii „Zastanych” warunków początkowych nie da się sprawiedliwie podzielić. Analizowaliśmy również obciążenia z nich wynikające, na które w kontekście bycia w relacji z drugą osobą można zwrócić uwagę.

52 Dlatego też nie można powiedzieć, że wypowiadamy się na temat np. socjalizmu czy totalitaryzmu.

53 Wytrzymałość materiału to wartość siły, jaką może przenieść jednostka powierzchni materiału obciążonego. Jeśli w którymś miejscu materiał będzie zbytnio obciążony (czy z powodu nadmiernej zbyt punktowo działającej siły czy też z powodu zbytniej niejednorodności budowy tego materiału), to całość może ulec „zniszczeniu”.

54 Tym samym możemy mówić o idei solidarności jako o idei, która jeśli realizowana jest sumiennie przez każdego członka danej wspólnoty, staje się niejako rękojmią sprawiedliwości międzyosobowej oraz wspólnotowej. Por. A. Stoiński, Przeobrażenia idei sprawiedliwości społecznej. Część III: Sprawiedliwość społeczna jako idea równości i solidarności, „Roczniki Filozoficzne” 66 (2018) nr 1, DOI: http://dx.doi.org/10.18290/rf.2018.66.1-7.

55 Zgodnie z utylitaryzmem czy też współczesnym liberalizmem.

56 Por. J. N. Mortensen, The Common Good: An Introduction to Personalism, Wilmington 2017.

57 Interesujące wydają się badania przeprowadzane pod kątem wpływu relacji interpersonalnych oraz relacji „przez Internet” na jakość życia. Okazuje się, że pierwsze tę jakość poprawiają, 
Daje to w konsekwencji nadzieję na potencjalne narzędzie, którego pozytywnych skutków, jak na razie, nie jesteśmy w stanie wycenić. Pomijanie zaś tego narzędzia musiałoby być zdeterminowane zdecydowanym i całkowicie pewnym założeniem o pozycji człowieka w świecie (wartość godności równa 0 lub nieskończenie mała wartość $1 / \omega$, co w efekcie daje status moralny równy bądź prawie równy ze statusem moralnym zwierząt), lub też ograniczeniem racjonalności celów działania, które to ograniczenie z jakichś powodów nie pozwala patrzeć „wyżej”, sięgać nie „po więcej”, lecz „dalej” 58 .

\section{Bibliografia}

Arystoteles, Etyka nikomachejska, Warszawa 1982.

Biesaga T., Godność a wolność w antropologii Karola Wojtyty, w: Ku rozumieniu godności człowieka, red. G. Hołub, P. Duchliński, Kraków 2008.

Biesaga T., Godność osoby ludzkiej a normy etyczne, w: Spór o naturę ludzką, red. A. Maryniarczyk, K. Stępień, A. Gudaniec, Lublin 2014, s. 567-584.

Błaszczyk P., Fila M., Cantor on Infinitesimals. Historical and Modern Perspective, „Bulletin of the Section of Logic” 49 (2020) No. 2, s. 149-179, DOI: http://dx.doi. org/10.18778/0138-0680.49.2.03.

Copleston F., Historia filozofii, t. 8, Warszawa 1989.

Dadaczyński J., Pojęcie boskiej wiecznej teraźniejszości w kontekście matematycznej analizy niestandardowej, „Logos i Ethos” 34 (2013), s. 31-43, DOI: http://dx.doi.org/10.15633/ lie.167.

drugie zaś nie. Por. P. S. N. Lee, L. Leung, V. Lo, Ch. Xiong, T. Wu, Internet Communication Versus Face-to-face Interaction in Quality of Life, „Social Indicators Research” 100 (2011), s. 375-389.

58 Można mieć tu na myśli kwestię zdeterminowania zachowań ludzkich do działania w biologiczno-materialistycznym obszarze życia, z powodu niespełnionych potrzeb podstawowego rzędu. Podobnie jak w systemie utylitarnym Johna Stuarta Milla, który rozróżniał przyjemności niższego oraz wyższego rzędu, tym pierwszym przypisując podstawową rolę. Por. S. Kowalczyk, Liberalizm i jego filozofia, Katowice 1995, s. 38. Choć, jak zauważa Władysław Zuziak, niekoniecznie nieograniczone spełnianie podstawowych potrzeb, postulowane przez współczesny liberalizm, prowadzi do tych wyższych. Zob. W. Zuziak, Czy możliwa jest etyka w życiu społecznym? Na marginesie lektury Arystotelesa i Alasdaira MacIntyre’a, „Analecta Cracoviensia” 30/31 (1998/1999), s. 89-102. 
Easton W. B., Powers of Regular Cardinals, „Annals of Mathematical Logic” 1 (1970), s. 139-178. Ehrlich P., The Rise of non-Archimedean Mathematics and the Roots of a Misconception I: The Emergence of non-Archimedean Systems of Magnitudes, „Archive for History of Exact Sciences” 60 (2006), s. 1-121, DOI: 10.1007/s00407-005-0102-4.

Fichtenholz G. M., Rachunek różniczkowy i całkowy, Warszawa 2012.

Gołota S., Dylematy mózgu. Poznanie i emocje w procesach oceny moralnej, Toruń 2019. Górecki O., Utylitaryzm - doktrynalna analiza ewolucji nurtu, „Annales. Etyka w życiu gospodarczym" 14 (2011) nr 1, s. 115-126.

Grygiel W., What is Invariant? On the Possibility and Perspectives on the Evolutionary Theology, „Studia Koszalińsko-Kołobrzeskie” 25 (2018), s. 83-101, DOI: 10.18276/ skk.2018.25-05.

Hohol M., Cipora K., Perspektywy i granice ucieleśnionego poznania matematycznego, w: R. Murawski, Filozofia matematyki i informatyki, Kraków 2015, s. 119-140.

Hołub G., Człowiek a świat naturalny. Wokół koncepcji egalitaryzmu gatunkowego Paula W. Taylora, „Logos i Ethos” 32 (2012) nr 1, s. 105-126.

Hołub G., Godność pacjenta jako człowieka - norma podstawowa etyki lekarskiej, „Medycyna Praktyczna" 9 (2013), s. 122-124.

Hołub G., Human Enhancement, the Person, and Posthuman Personhood, „Ethics \& Medicine. An International Journal of Bioethics” 32 (2016) No. 3, s. 171-183.

Hołub G., Osoba w labiryncie decyzji moralnych. Bioetyka w perspektywie personalistycznej, Kraków 2014.

Ingarden R., Książeczka o człowieku, Kraków 2017.

Jaspers K., Sytuacje graniczne, w: R. Rudziński, Jaspers, Warszawa 1978.

Kowalczyk S., Liberalizm i jego filozofia, Katowice 1995.

Kymlicka W., Współczesna filozofia polityczna, Warszawa 2009.

Lee P. S. N., Leung L., Lo V., Xiong Ch., Wu T., Internet Communication Versus Face-to-face Interaction in Quality of Life, „Social Indicators Research” 100 (2011), s. 375-389.

Nelson E., Internal Set Theory, http://web.math.princeton.edu/ nelson/books/1.pdf (20.11.2018).

Nietzsche F., Z genealogii moralności, Łódź-Wrocław 2009-2010.

Mortensen J. N., The Common Good: An Introduction to Personalism, Wilmington 2017. Pala A., Godność - wolność - miłość: struktura dynamizmu życia osobowego człowieka w ujęciu Karola Wojtyły, „Logos i Ethos” 50 (2019) nr 2, s. 7-25, DOI: http://dx.doi. org/10.15633/lie.3475. 
Platon, Państwo, t. 1, Warszawa 1991.

Powszechna Deklaracja Praw Człowieka, Paryż 1948, http://libr.sejm.gov.pl/tek01/txt/ onz/1948.html (20.11.2018).

Robinson A., Non-standard Analysis, Princeton 1996.

Sandel M. J., Sprawiedliwość. Jak postępować stusznie, Warszawa 2013.

Schweitzer A., More from the Primeval Forest, London 1931.

Stoiński A., Przeobrażenia idei sprawiedliwości społecznej. Część III: Sprawiedliwość społeczna jako idea równości i solidarności, „Roczniki Filozoficzne” 66 (2018) nr 1, DOI: http://dx.doi.org/10.18290/rf.2018.66.1-7.

Stroyan K. D., Mathematical Background: Foundations of Infinitesimal Calculus, New York 1997, http://www.math.uiowa.edu/ stroyan/research.htm (20.11.2018).

Synowiec J., Model argumentacji etycznej w etyce personalistycznej Karola Wojtyty i Tadeusza Stycznia, Kraków 2014.

Szostek A., Wolność - prawda - sumienie, „Ethos” 4 (1991) nr 15/16, s. 32-33.

Tischner J., Etyka solidarności oraz Homo sovieticus, Kraków 2005.

Treliński G., Stosowane matematyki jako problem dydaktyki matematyki, Kraków 1982.

Walton D. N., Ethical argumentation, Lanham-Toronto 2009.

Williams T. D., Bengtsson J. O., Personalism, https://plato.stanford.edu/entries/personalism/ (2.09.2020).

Wojtyła K., Elementarz etyczny, Lublin 1983.

Wojtyła K., Miłość i odpowiedzialność, Lublin 2001.

Woodin H., The Continuum Hypothesis. Part I, „Notices of the AMS” 48 (2001) No. 6, s. 567-576; Part II: „Notices of the AMS” 48 (2001) No. 7, s. 681-690.

Woźniak C., Analiza niestandardowa w mechanice newtonowskiej punktu materialnego, „Journal of Theoretical and Applied Mechanics” 19 (1981), s. 355-374.

Woźniak W., Nierówności społeczne i ich dziedziczenie jako problem strukturalny i polityczny, w: Nierówności społeczne w Polsce, red. B. Kłos, J. Szymańczak, Warszawa 2014.

Wójtowicz K., Status hipotezy continuum w świetle koncepcji Woodina, „Filozofia Nauki” 76 (2011) nr 4, s. 67-82.

Zuziak W., Czy możliwa jest etyka w życiu społecznym? Na marginesie lektury Arystotelesa i Alasdaira MacIntyre’a, „Analecta Cracoviensia” 30/31 (1998/1999), s. 89-102.

Zuziak W., Uczciwość a ideały społeczne. W poszukiwaniu nowego wzorca, „Logos i Ethos” 49 (2019) nr 1, s. 161-179, DOI: http://dx.doi.org/10.15633/lie.3440. 


\begin{abstract}
Abstrakt
Modele wartości godności człowieka i kwestia sprawiedliwości

W niniejszym artykule podejmujemy próbę przeanalizowania relacji pomiędzy różnymi wartościami godności ludzkiej a sposobem definiowania sprawiedliwości. Rozróżniamy następujące możliwości: godność ma wartość 0 (lub 1/ $\omega$ ), skończoną $G$ lub nieskończoną (rozumianą na dwa sposoby: jako granica i jako liczba hiperrealna $K$ ). Przypisanie wartości nieskończonej godności człowieka będzie tożsame z przyjęciem głównych założeń personalistycznych odnośnie do godności osoby. Rozumowanie przeprowadzamy, wykorzystując podstawowe narzędzia modelowania matematycznego. Bierzemy również pod uwagę wartość materialną „warunków początkowych” każdego człowieka, określoną w odniesieniu do danego społeczeństwa i czasu, ale zróżnicowaną dla poszczególnych ludzi. Pokazujemy, że w kontekście problemu sprawiedliwości jest to dodatkowa płaszczyzna badawcza. Proponujemy w efekcie metaetyczną przestrzeń dialogu między personalizmem a utylitaryzmem.
\end{abstract}

\title{
Słowa kluczowe
}

godność, osoba ludzka, sprawiedliwość, nieskończoność, nieskończenie małe, personalizm, utylitaryzm

\section{Abstract}

\section{The models of human dignity values and the issue of justice}

In this article we attempt to analyze the relationship between different values of human dignity and the way justice is defined. We study the following possibilities: dignity has a value of 0 (or $1 / \omega$ ), a finite value $G$ or infinite (understood in two ways: as a limit and as hyperreal number $K$ ). The attribution of the value of infinite human dignity will is it the same as the adoption of the main personalistic assumptions about the dignity of the person. The reasoning is carried out using basic mathematical modelling tools. We also take into account the material value of each person's "initial conditions," defined in relation to a given society and time, but differentiated for individual people. We show that, in the context of the problem of justice, these "initial conditions" create an additional 
research area. In effect, we propose a metaethical space for dialogue between personalism and utilitarianism.

\section{Keywords}

dignity, person, human person, justice, infinity, infinitesimals, personalism, utilitarianism 